\title{
APPLICATION OF OLIGONUCLEOTIDE MICROARRAY FOR THE DETECTION AND GENOTYPING OF CRY GENES IN Bacillus thuringiensis
}

\author{
Liu Xu-Guang ${ }^{1,2}$, Song Fu-Ping ${ }^{1}$, Wen Si-Yuan ${ }^{3}$, Wang Sheng-Qi ${ }^{3}$, Huang Da-Fang ${ }^{4}$, and Zhang Jie ${ }^{1^{*}}$
}

\begin{abstract}
We have developed a parallel, rapid, high-throughput oligonucleotide microarray-based assay for the reliable detection and genotyping of three cry genes (cry1, cry2 and cry9) in Bacillus thuringiensis (Bt). After the nonpolymerase chain reaction (PCR), amplified Bt genomic DNA were fluorescent-labeled using a random primer. The corresponding oligonucleotide probes were designed for the different cry genes that can hybridize Bt genomic DNA after cluster analysis and were printed on glass slides. This microarray has unambiguously detected and identified the cry genes in 10 isolates and reference Bt. Our data demonstrates that the microarray assay is simple and rapid for the detection and genotyping of genes. This type of assay is also a potentially valuable tool for identification and characterization of bacterial functional genes in general.
\end{abstract}

Keywords: oligonucleotide microarray, cry genes, genotyping, random primer labeling, bioinformatics.

\section{INTRODUCTION}

Bacillus thuringiensis $(\mathrm{Bt})$ is capable of producing highly poisonous crystal proteins (also called $\beta$-endotoxin) that kill Lepidoptera insects and other agricultural pests. More than 375 crystal protein genes have already been cloned and sequenced. Based on amino acid sequence similarity, Crickmore (2003) categorized these endotoxins into 55 groups $\left(1^{\text {st }}\right.$ level$), 106$ subgroups $\left(2^{\text {nd }} l e v e l\right), 173$ types ( $3^{\text {rd }}$ level), and 375 subtypes ( $4^{\text {th }}$ level). Bt has become the most effective biopesticide in the biological control of agricultural pests. With the development of biotechnology, new $\beta$-endotoxin genes are continually being isolated and cloned. Along with the development in the study of toxin structure and functions, genetic modification of the toxin genes has increased the effectiveness and specific targeting ability of these endotoxins and widened the application perspective. Identification of Bt resources is essential to predict the pesticide effect, rapid screening for desirable isolates, and cloning of novel toxin genes.

\footnotetext{
${ }^{1}$ Institute of Plant Protection (CAAS), State Key Laboratory for Biology of Plant Diseases and Insect Pests, Beijing 100094, China. *Corresponding author (jzhang@ippcaas.cn).

${ }^{2}$ Lianyungang Teachers College, Lianyungang 222206, China.

${ }^{3}$ Beijing Institute of Radiation Medicine Science, Beijing 100850, China.

${ }^{4}$ Institute of Biotechnology, Chinese Academy of Agricultural Sciences, Beijing 100081, China.

Received: 28 October 2008.

Accepted: 22 April 2009.
}

Current detection and identification methods of $\mathrm{Bt}$ cry genes are based on polymerase chain reaction (PCR), including PCR-restriction fragment length polymorphism (RFLP) (Song et al., 2003), PCR-single-strand conformation polymorphism (SSCP), PCR-sequencing, and Multiplex PCR. These methods are rapid and sensitive. However, they become complicated, tedious, and time-consuming for analyzing multiple genes.

The development of DNA microarray has enabled the rapid, parallel, and high throughput detection and identification of microbes (Gabig and Wegrzyn, 2001; Bodrossy et al., 2003). DNA microarray is not only manufactured by light-directed in situ synthesis, but is also produced by DNA probe fixation (PCR products, synthetic oligonucleotides) on solid surfaces. This microarray is then hybridized with nucleic acid samples. Information about the nucleotide sequences can be rapidly and accurately obtained on a large scale (Small et al., 2001; Hwang et al., 2003). In this study, we report the development of an oligonucleotide microarray that can be used to detect and identify cryl, cry 2 , and $\operatorname{cry} 9$ genes in Bt.

\section{MATERIALS AND METHODS}

\section{Strains and culture media}

The 10 Bt strains used (G03, HD-73, and Ly30, etc.) are collections from the authors' laboratory. These strains are cultured in Luria-Bertani (LB) medium 
(containing tryptone, yeast extract, sodium chloride, and microbiologically tested agar).

\section{Total DNA isolation}

Bacillus thuringiensis strains were activated in LB at $30{ }^{\circ} \mathrm{C}$ overnight. Activated bacteria were diluted in LB (1:100), incubated at $37^{\circ} \mathrm{C}$ for $4 \mathrm{~h}$, and shaken $(230 \mathrm{rpm})$ until $\mathrm{OD}_{600}=2.0$. Cells were collected by centrifugation and then resuspended in solution $\mathrm{I}\left(0.3 \mathrm{~mol} \mathrm{~L}^{-1}\right.$ sucrose, 25 mmol L-1 Tris-HCl [pH 8.0], 25 mmol L-1 EDTA, $50 \mathrm{mg}$ $\mathrm{mL}^{-1}$ lysozyme). For each $100 \mathrm{~mL}$ culture, $3 \mathrm{~mL}$ of solution I was used. Suspension was incubated at $37^{\circ} \mathrm{C}$ for 1 to 2 $\mathrm{h}$ and then solution II was added $\left(0.1 \mathrm{~mol} \mathrm{~L}^{-1} \mathrm{NaCl}, 0.1 \%\right.$ sodium dodecyl sulphate [SDS], $0.1 \mathrm{~mol} \mathrm{~L}^{-1}$ Tris- $\mathrm{HCl}[\mathrm{pH}$ 8.0]). Bacterial cells were disrupted by repeated freezethaw until the solution became clear. Lysate was extracted twice with phenol: chloroform: isoamyl alcohol (25:24:1) and once with chloroform:isoamyl alcohol (24:1). DNA was precipitated by adding $1 / 10$ volume of $3 \mathrm{~mol} \mathrm{~L}^{-1}$ sodium acetate ( $\mathrm{pH}$ adjusted to 5.2 with glacial acetic acid) and $2 \times$ volume of absolute ethanol. Precipitate was separated by spinning, washed twice with $70 \%$ ethanol, once with absolute ethanol, and dried in a vacuum. DNA was resuspended in ultrapure water, analyzed with $0.7 \%$ agarose gel electrophoresis $\left(5 \mathrm{~V} \mathrm{~cm}^{-1}\right)$, and quantified with UV spectrophotometry (DU® 640, Beckman Coulter, Fullerton, California, USA).

\section{Oligo probe design and synthesis}

Nucleotide sequences for cry1, cry2, and cry9 were retrieved from the National Center for Biotechnology Information (NCBI, Bethesda, Maryland, USA) and saved in the local BioEdit database. Probes were designed by Vector NTI, Array Designer 2.0 software after eliminating non-coding sequences in these genes.

Oligonucleotide probes were synthesized with the conventional phosphoramidite method with $\mathrm{ABI}$ 8089 (USA). Oligos were released by incubation with concentrated ammonium at $55{ }^{\circ} \mathrm{C}$ for $15 \mathrm{~h}$ followed by column purification. Probes were linked by a spacer (PEG-phosphoramidite) to modified 3'-amine.

\section{Chip manufacture}

In the microarray, each cry gene was distinguished by three corresponding oligonucleotide probes (Figure 1, Table 1). Probes were mixed with a printing solution (3 $\times$ SSC [sodium chloride/sodium citrate], $0.01 \%$ SDS) concentrated to $40 \mu \mathrm{mol} \mathrm{L} \mathrm{L}^{-1}$ and printed on glass slides with Cartisan (Cartesian Technologies, Delaware, USA). Each print has a volume of about $0.5 \mathrm{~nL}$. The distance between two spots was $500 \mu \mathrm{m}$ and spot diameter was 200 $\mu \mathrm{m}$. Each spot was printed twice. Printing temperature was controlled at $23{ }^{\circ} \mathrm{C}$ and relative humidity was $90 \%$. Slides were kept at room temperature for at least 24 $\mathrm{h}$ before hybridization. Sixty-three probes and empty controls were arranged in a $10 \times 13$ array. The location of the probes is listed in Table 1 . A1 A2 was the empty control and M9M10 was the negative control.

\section{Random labeling of genomic DNA (Brown, 2000)}

Genomic DNA was quantified by spectrophotometry, labeled with high-concentration Klenow enzyme and random primer. Labeling volume was $50 \mu \mathrm{L}$ containing $5 \mu \mathrm{L}$ of $10 \times$ buffer, $30 \mu \mathrm{g}$ of genomic DNA, $5 \mu \mathrm{L}$ of 10 $\times$ dNTP mix (dATP, dGTP, dCTP each $1.2 \mathrm{mmol} \mathrm{L}^{-1}, 0.6$ mmol L ${ }^{-1}$ dTTP), $3 \mu \mathrm{L}$ of Cy 3 or Cy 5 dUTP (Amersham), $5 \mu \mathrm{L}$ of hexamer primer, $50 \mathrm{U}^{-1} \mathrm{~L}^{-1}$ of Klenow DNA polymerase (Invitrogen or New England Biolabs [NEB]). Reaction mix was incubated at $37^{\circ} \mathrm{C}$ for $2 \mathrm{~h}$, inactivated in boiling water for $10 \mathrm{~min}$, and chilled on ice. Labeled DNA was analyzed with $0.7 \%$ agarose gel electrophoresis and Typhoon 9410 scanner (GE Healthcare Bio-Sciences AB, Uppsala, Sweden). The probe was precipitated and suspended in $2 \mu \mathrm{L}$ ultrapure water and $8 \mu \mathrm{L}$ hybridization buffer $(6 \times$ SSC, $0.5 \%$ SDS, $5 \times$ Denhart's reagents, 0.1 $\mu \mathrm{g} \mu \mathrm{L}^{-1}$ salmon sperm DNA).

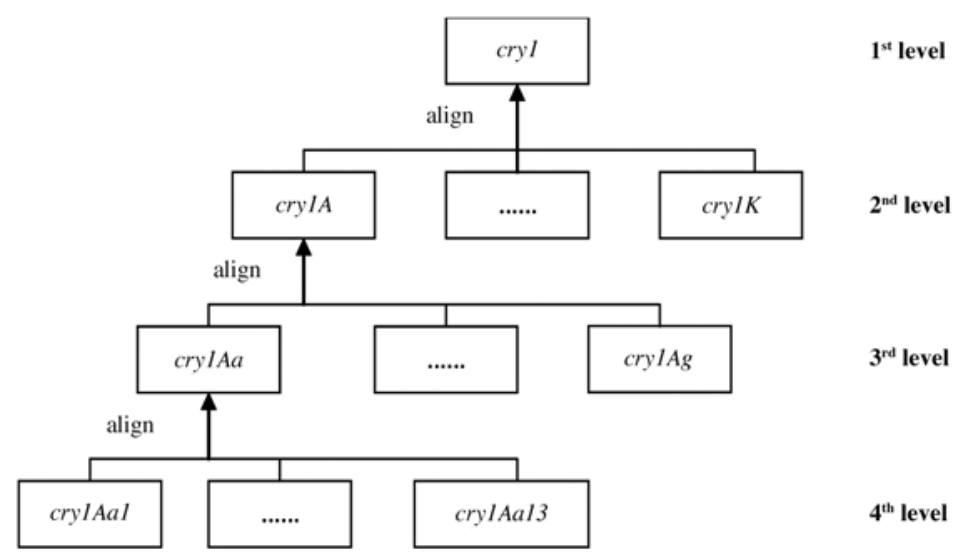

Figure 1. Strategy for designing a probe to detect and determine the genotype of Bt cry1, cry2, and cry9 genes. 
Table 1. Probes for detection and typing of Bt cry1, cry2, and cry9 genes.

\begin{tabular}{|c|c|c|c|c|c|}
\hline Name & Sequence (5’-3') & Length & $\mathbf{T m}$ & GC\% & $\begin{array}{c}\begin{array}{c}\text { Location } \\
\text { (row- } \\
\text { column) }\end{array} \\
\end{array}$ \\
\hline $01 \mathrm{Aa}$ & GCCTCCCTAACGACCAACTTGCCTTCCACTATATATAGAC & 40 & 69.5 & 47.5 & $\mathrm{~A} 3, \mathrm{~A} 4$ \\
\hline $01 \mathrm{Ab} 1^{\mathrm{a}}$ & CGTTTCTCTATTTCCGAACTATGATAGTAGAACGTATCCA & 40 & 65 & 37.5 & $\mathrm{~A} 5, \mathrm{~A} 6$ \\
\hline $01 \mathrm{Ab} 2^{\mathrm{a}}$ & GATATGACGGAGCCTATGAAAGCAATTCTTCTGTACCAGC & 40 & 68.6 & 45 & $\mathrm{~A} 7, \mathrm{~A} 8$ \\
\hline $01 \mathrm{Ac}$ & CGAGTTCGTGTACGGTATGCTTCTGTAACCCCGATTCACCTCAACG & 46 & 74.4 & 52.2 & A9,A10 \\
\hline $01 \mathrm{Ad}$ & GCTGAGTATGCGCCAGTTTATGAGGAAGCATATATAGATGG & 41 & 68 & 43.9 & $\mathrm{~B} 1, \mathrm{~B} 2$ \\
\hline $01 \mathrm{Ae}$ & GGAACTTTCATCGTGGATAGTGTAGAATTATTCCTCATGGAAG & 43 & 67 & 39.5 & $\mathrm{~B} 3, \mathrm{~B} 4$ \\
\hline 01Af & GCAATTACATTATCAGTTCAGAGAGTGTCATGTGTGGACAAAGGTCGG & 48 & 71.6 & 43.8 & B5,B6 \\
\hline $01 \mathrm{Ag}$ & CACTGTTTCTTCTCCTTGTTCTCTTGATACATGCTAGGTCGA & 42 & 68.9 & 42.9 & $\mathrm{~B} 7, \mathrm{~B} 8$ \\
\hline $01 \mathrm{~A}$ & TCAATGACATGAACAGTGCCCTTACAACCGCTATTCCTCT & 40 & 70.4 & 45 & B9,B10 \\
\hline $01 \mathrm{Ba}$ & GTAAAAGCATCCGAACTTCCTCAAGGTACCACTGTTGTTA & 40 & 68.4 & 42.5 & $\mathrm{C} 1, \mathrm{C} 2$ \\
\hline $01 \mathrm{Bb}$ & GAATCTTCATTCAGGTGTTACTGTTGTTGGAGGGCCAGGA & 40 & 70.7 & 47.5 & $\mathrm{C} 3, \mathrm{C} 4$ \\
\hline $01 \mathrm{Bc}$ & ACTGAGAATCAAGGTACAAGAACGTGCGGTAATGAATGTGGT & 42 & 70.5 & 42.9 & $\mathrm{C} 5, \mathrm{C} 6$ \\
\hline 01Bd & ACTGGTGGAGACGTAGTTAGATTGAATAGGAATAATGGTAAT & 42 & 65.8 & 35.7 & $\mathrm{C} 7, \mathrm{C} 8$ \\
\hline 01Be & GCTATGACACGCGTGTTTATCCAATGAATACCAGTGCTCAA & 41 & 70.1 & 43.9 & $\mathrm{C} 9, \mathrm{C} 10$ \\
\hline $01 \mathrm{Bf}$ & GGTTATCTCACATAGGGCTCATTTCACAATCTAGGGTGCA & 40 & 69.1 & 45 & $\mathrm{D} 1, \mathrm{D} 2$ \\
\hline 01B & CGCATCAACAGTCCAAACGGGTATTAACATAGCTGGTAGAA & 41 & 69.5 & 43.9 & D3,D4 \\
\hline $01 \mathrm{Ca}$ & GCACGAGTTATAGTATTAACAGGAGCGGCATCCACAGGAG & 40 & 70.5 & 50 & D5,D6 \\
\hline $01 \mathrm{Cb}$ & TCTGGCAGTCAAGGTGCATCAATAAGTATTAGTAATAATGT & 41 & 65.4 & 34.1 & D7,D8 \\
\hline $01 \mathrm{C}$ & CTGGATTTGAAGTACCCCTTTTATCCGTTTATGCTCAAGCGGC & 43 & 71.3 & 46.5 & D9,D10 \\
\hline 01Da & AGGTCTATGTTAGAGCGTTTAGCGACTGGGAGAAAGATCCTACT & 44 & 71 & 45.5 & E1,E2 \\
\hline $01 \mathrm{Db}$ & AAAATTTAGAGGGATCTCGATTGTCAGATTGGGTTGTATAT & 41 & 65.3 & 34.1 & $\mathrm{E} 3, \mathrm{E} 4$ \\
\hline 01D & CTCGTTCGTTCGCTCATACAACACTCTTCACTCCAATAACCT & 42 & 70.4 & 45.2 & E5,E6 \\
\hline $01 \mathrm{Ea}$ & TACTGTAGCAACAAACATCGCCTTGGAGATTAGTCGTCTG & 40 & 69.3 & 45 & E7,E8 \\
\hline $01 \mathrm{~Eb}$ & AGTAACGTAGCAGCAGAAATCGGCTTGGGGCTTAGTCGTCT & 41 & 73.6 & 51.2 & E9,E10 \\
\hline $01 \mathrm{E}$ & ACGCGGGAAGTATATACAGATCCGGTAATTAATATAACTGA & 41 & 65.7 & 36.6 & $\mathrm{~F} 1, \mathrm{~F} 2$ \\
\hline $01 \mathrm{Fa}$ & ACATTCCCAATGAGCCAGAGTAGTTTCACAGTAGGTGCTGA & 41 & 71.1 & 46.3 & $\mathrm{~F} 3, \mathrm{~F} 4$ \\
\hline $01 \mathrm{Fb}$ & GCTGTAAAAGCACACAATCTTCATTCGGGTTCTACGGTTG & 40 & 69.6 & 45 & $\mathrm{~F} 5, \mathrm{~F} 6$ \\
\hline $01 \mathrm{~F}$ & GGGAGGACACTTAGTTAGTTCACGAAATACGGCTGGTAACC & 41 & 70.4 & 48.8 & $\mathrm{~F} 7, \mathrm{~F} 8$ \\
\hline $01 \mathrm{Ga}$ & ACGACAAGAAATAACAGAGTTAGAAAGGAATAGAGCGACTGC & 42 & 68.1 & 40.5 & F9,F10 \\
\hline $01 \mathrm{~Gb}$ & CGCAAGAGGGCAAGCAATTCAGAGACTAGTAGGGTTTGGAAGG & 43 & 72.9 & 51.2 & $\mathrm{G} 1, \mathrm{G} 2$ \\
\hline $01 \mathrm{G}$ & ACCGTTAGTAAAGGCTTTCAATCTTCATTCAGGTGCCACG & 40 & 70.1 & 45 & $\mathrm{G} 3, \mathrm{G} 4$ \\
\hline 01Ha & AGCAAATAGCAGTGGTGTATTTAGGCATTTACCGCAACCTTCGT & 44 & 71.9 & 43.2 & G5,G6 \\
\hline $01 \mathrm{Hb}$ & ACCTTAGGAGCTTTAAGAGTGACCCTTACAGGACAATTACCACAA & 45 & 70.4 & 42.2 & G7,G8 \\
\hline $01 \mathrm{H}$ & CTTGGAGATAGTTATGAAGTGTATATTGAGTCGCTTAGAGAATGG & 45 & 66.5 & 37.8 & G9,G10 \\
\hline 01Ia & ACACAAATGTATCCAATTAAAACTACAGCCCAACTTACAAGA & 42 & 66.2 & 33.3 & $\mathrm{H} 1, \mathrm{H} 2$ \\
\hline $01 \mathrm{Ib}$ & GCACTTTCAGACTTGAGAGGATTAGGTGATGCTTTAGCCGTC & 42 & 70.8 & 47.6 & $\mathrm{H} 3, \mathrm{H} 4$ \\
\hline $01 \mathrm{Ic}$ & GATATCGAGTTAATGGTATTAGATTTAGTTCGCGTATTCCCAAGC & 45 & 67.2 & 37.8 & $\mathrm{H} 5, \mathrm{H} 6$ \\
\hline 01Id & TCCACATTTTATAACCGCCAATCTAGTCAAACACAGGAAT & 40 & 67.1 & 37.5 & $\mathrm{H} 7, \mathrm{H} 8$ \\
\hline 01Ie & TTGGATTAAAAATCGCAACAACGCAAGGGCTACAAGTGTT & 40 & 69.7 & 40 & $\mathrm{H} 9, \mathrm{H} 10$ \\
\hline $01 \mathrm{I}$ & TTCAGCAACTATGAATAGAGGAGAGGACTTAGACTATAAA & 40 & 64 & 35 & $\mathrm{I} 1, \mathrm{I} 2$ \\
\hline 01Ja & AGATCCTGATAACGAAGCGGCTAAAAGTAGAGTAATTGAT & 40 & 66.3 & 37.5 & $\mathrm{I} 3, \mathrm{I} 4$ \\
\hline $01 \mathrm{Jb}$ & TTTCACCCCCGCCATCTGCAAGATACAGAAATCCTGGAAC & 40 & 72.1 & 50 & I5,I6 \\
\hline $01 \mathrm{Jc}$ & AATGCGGTACAGCGTTATCGAATTAGAATGCGTTATGCGGC & 41 & 71.7 & 46.3 & I7,I8 \\
\hline 01Jd & ACTCATTTCCGAATCCCATTTCAGGCAAACACTCCACAAAGGT & 43 & 72 & 44.2 & I9,I10 \\
\hline $01 \mathrm{~J}$ & GGATGGGGAGAGGATATTACCTGATATCGATCCACTCGAAGTTTC & 45 & 70.4 & 46.7 & $\mathrm{~J} 1, \mathrm{~J} 2$ \\
\hline
\end{tabular}


Continuation Table 1.

\begin{tabular}{|c|c|c|c|c|c|}
\hline $01 \mathrm{Ka}$ & CGTGGATGGATAGGAAGCACTGGTATTAGCATTCAAGGAGGCG & 43 & 72.7 & 51.2 & $\mathrm{~J} 3, \mathrm{~J} 4$ \\
\hline $01-2^{b}$ & GAGGCAGAATATGATTTAGAAAGAGCACAAAAGGCGGTGAATG & 43 & 70.5 & 42 & $\mathrm{~J} 5, \mathrm{~J} 6$ \\
\hline $01-3^{\mathrm{b}}$ & GGTCGTGGCTATATCCTTCGTGTCACAGCGTACAAAGAGGGATATGGAGA & 50 & 74.8 & 50 & $\mathrm{~J} 7, \mathrm{~J} 8$ \\
\hline $01-4^{\mathrm{b}}$ & GAAGTTTATATAGATCGAATTGAATTTGTTCCGGTAGAAGTAAC & 44 & 64.2 & 31.8 & $\mathrm{~J} 9, \mathrm{~J} 10$ \\
\hline 2Aa & CACAACTTTAATTGCAGCACGGTCCTCCCTCCTTTATCAA & 40 & 70 & 45 & $\mathrm{~K} 1, \mathrm{~K} 2$ \\
\hline $02 \mathrm{Ab}$ & TGGAGGAATTTCGTCTGGTGATATAGGTGCATCTCCGTTT & 40 & 70 & 45 & $\mathrm{~K} 3, \mathrm{~K} 4$ \\
\hline 02Ac & GAGTGTCATCTAGCCGCATAGGTCAAGCTAATCTTAATCA & 40 & 67.7 & 42.5 & $\mathrm{~K} 5, \mathrm{~K} 6$ \\
\hline $2 \mathrm{Ad}$ & CCGGCTTTAGTGGGGCTAGTCTTTT & 40 & 66.9 & 40 & ,K8 \\
\hline $02 \mathrm{~A}$ & ACGCTTAGAGGGAATGGAAATAGTTACAATCTTTATTTAAGAGT & 44 & 65.4 & 31.8 & K9,K10 \\
\hline 09Aa & TGCTACACAA & 41 & 67.4 & 39 & ,L2 \\
\hline 09Ba & CCAAATGAACCTATCAGTAGAAGT & 43 & 70 & 44.2 & $\mathrm{~L} 3, \mathrm{~L} 4$ \\
\hline $09 \mathrm{Ca}$ & CGTGGAGGGGTTTCTATCGGTGATGTTAGATTAGGGAGCACAATGA & 46 & 72.7 & 47.8 & L5,L6 \\
\hline 09Da & ГAGGGCATTGGATGACCTAACTGGA & 44 & 72.4 & 47.7 & L7,L8 \\
\hline 09Ea & CGAAGAACGGACGGTGGTGCAGTTGGAACGATTAGAGCTAATGT & 44 & 73.7 & 50 & L9,L10 \\
\hline $09 \mathrm{~Eb}$ & AGCAGTAGTAGGGACAGCAGCGGATCATTTAACGGGATTACACGA & 45 & 73.7 & 48.9 & $\mathrm{M} 1, \mathrm{M} 2$ \\
\hline 09E & AGTTACGGTCAGATTACCTCTAACACACGTTTATTCAATACGACT & 45 & 68.4 & 37.8 & M3,M4 \\
\hline 9 & GGATTGCTGTGAAGCGGCTCAAACACATGAGTTTTCTTCCTATATT & 46 & 71 & 41.3 & M5,M6 \\
\hline $\operatorname{vip} 3 \mathrm{Aa}^{\mathrm{c}}$ & GCTTAAATGATCTTATCGCACAGGGAAACTTAAATACAGA & 40 & 65 & 35 & M7,M8 \\
\hline lec ${ }^{\mathrm{d}}$ & TTGCCAGCTTCGCCGCTTCCTTCAACTTCACCTTCTATGC & 40 & 75.2 & 52.5 & M9,M10 \\
\hline
\end{tabular}

${ }^{\mathrm{a}}$ For the detection and typing of $c r y l \mathrm{Ab}$; ${ }^{\mathrm{b}}$ For the detection and typing of $\mathrm{cry} 1$; ${ }^{\mathrm{c}}$ For the detection of vip $3 \mathrm{Aa}$; ${ }^{\mathrm{d}}$ For the detection of LECTIN (negative control); Tm: DNA melting temperature; GC\%: guanine-cytosine content.

\section{Hybridization and washing}

The chip was pretreated with hybridization buffer at room temperature for $1 \mathrm{~h}$, then hybridized with $10 \mu \mathrm{L}$ probe. It was placed in a box and incubated at $56^{\circ} \mathrm{C}$ for $2 \mathrm{~h}$, and washed with buffers A $(1 \times \mathrm{SSC}, 0.2 \% \mathrm{SDS}), \mathrm{B}(0.2 \times$ $\mathrm{SSC}), \mathrm{C}(0.1 \times \mathrm{SSC})$ for $1 \mathrm{~min}$ each. It was finally spun dried (Wen et al., 2003).

\section{Microarray scanning and data analysis}

The microarray was scanned with GenePix 4000 (Axon Instrument, Foster City, California, USA) at $530 \mathrm{~nm}$ excitation, $585 \mathrm{~nm}(\mathrm{Cy} 3)$ and $650 \mathrm{~nm}$ (Cy5) emission. PMT was 700 to 800 . Power level was $33 \%$ to $100 \%$. Image resolution was $10 \mu \mathrm{m}$ in 16 bit tiff format. Signal intensity was the mean value of the two spots after background subtraction.

\section{RESULTS}

\section{Oligonucleotide probes for gene detection and typing}

Nucleotide sequences (131 entries) of cryl, cry2, and cry9 were retrieved from the NCBI database. After removing non-coding sequences, they were deposited in a local Bioedit database for local BLAST. Sequences were aligned with the strategy described in Figure 1 using ClustalW from the Vector NTI package (Invitrogen, Carlsbad, California, USA). Thirteen sequences, crylAal cryl Aal3, were first aligned and a consensus sequence crylAa was obtained. Probes were designed by Array Designer 2.0 based on the consensus sequence. Melting temperature of the probe was $70 \pm 5{ }^{\circ} \mathrm{C}$, sizes were 40 to $50 \mathrm{bp}$, hairpin maximum $\Delta \mathrm{G}$ was $-3.0 \mathrm{kcal} \mathrm{mol}^{-1}$, self-dimer maximum $\Delta \mathrm{G}$ was -6.0 $\mathrm{kcal} \mathrm{mol}^{-1}$, and the run/repeat (dinucleotide) maximum length was $4 \mathrm{bp}$. A specific oligonucleotide probe, 01Aa, for crylAa gene detection and typing was obtained after the probe sequences were searched with local BLAST to ensure specificity. Those with $E$ value smaller than $1 \mathrm{e}^{-10}$ and specificity score greater than 70 were selected (Liu et al., 2004). Similarly, consensus sequences of cryl $A b$... crylAg were obtained and corresponding oligonucleotide probes $01 \mathrm{Ab} \ldots 01 \mathrm{Ag}$ obtained. After consensus, crylA was obtained by aligning the sequences of crylAa... cry $1 \mathrm{Ag}$, and the 01A probe was obtained. In the same way, we got the consensus sequences $\operatorname{cry} 1 B \ldots c r y l K$ and the $01 \mathrm{~B} \ldots 01 \mathrm{~K}$ probes. Furthermore, we got a consensus sequence cryl by aligning the sequences of crylA... cry $1 K$, and 01 probes were obtained.

In this method, the crylAal gene could be distinguished by three probes: $01,01 \mathrm{~A}$, and $01 \mathrm{Aa}$, and we called this method TPPS (Three-Ply Position System).

We designed a total of 63 probes. Information regarding the probes (sequences, Tm, size, GC\%, and location on chip) is listed in Table 1. 


\section{Random labeling of genomic DNA}

Genomic DNA was fragmented during fluorescent labeling. By controlling the amount of random primer, the labeled probe was concentrated in a smear band of $1000 \mathrm{bp} \sim 150 \mathrm{bp}$. Since the non-fluorescent bands cannot be registered in the Typhoon scanner, the smear band (II) image in Figure 2 is different from the other two lanes.

I

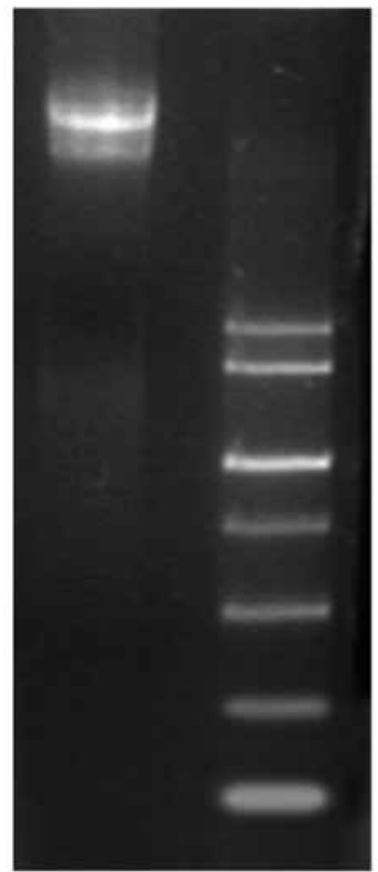

I: Genomic DNA; II: Labeling product; M: Marker DGL2000.

Figure 2. Random labeling of prepared products and total DNA.
This figure shows that genomic DNA was randomly fragmented and successfully labeled with fluorescent dye.

\section{Hybridized fluorescent images}

Figure 3 shows the hybridized fluorescent images with partial Bt of Ly30, G03, and HD-73. The cry genes in these strains were examined with Polymerase Chain Reaction-Restriction Fragment Length Polymorphism (PCR-RFLP).

The fluorescence signal was weaker than that obtained from the PCR-based probe because of the small size of the oligonucleotide probe. After optimizing hybridization parameters, cry genes in the different strains can be appropriately distinguished with the corresponding probes. The result of chip hybridization is consistent with PCR-RFLP (Yao et al., 2003).

\section{DISCUSSION}

Nowadays, for an important agricultural pest such as Lepidoptera insects, Bt is widely and effectively used as a critical biopesticide in biocontrol. It is significantly necessary to screen a Bt isolate with high toxicity and clone its novel insecticidal toxin genes to construct genetically engineered bacteria and transgenic plants. Among the insecticidal toxin genes against Lepidoptera, the most important are the cryl, cry2, and cry9 genes. In this study, we used an oligonucleotide microarray to detect and identify cry 1 , cry 2 , and cry9 genes in Bt.

At this time, methods for the detection and identification of Bt cry genes are based on PCR. One method is multiplex PCR (Bourque et al., 1993; Jaoua et al., 1996) and another is the two-step multiplex PCR (Ceron et al., 1995; Juarez-Perez et al., 1997). These methods, which include more than one primer, are applied

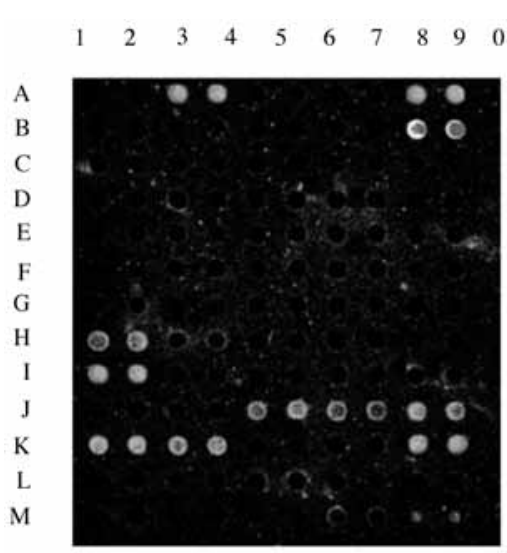

A

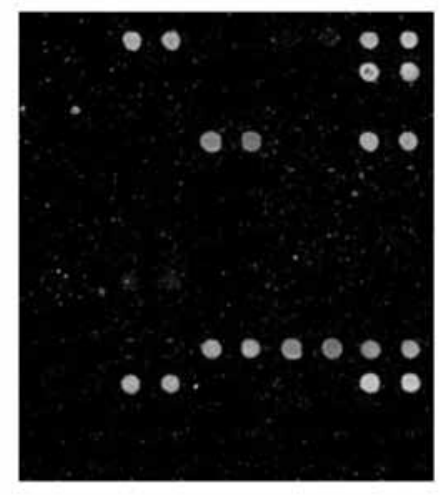

B

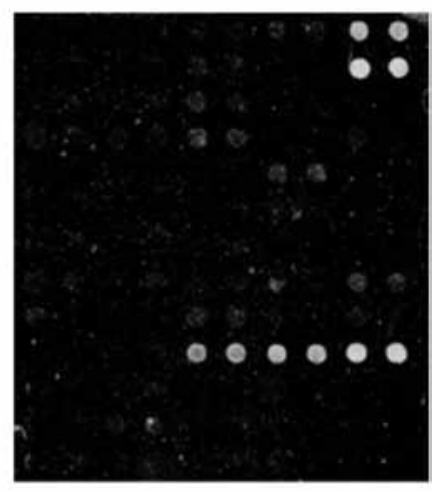

C

Figure 3. Fluorescent images of microarray hybridized with Ly30 (A), G03 (B), and HD73 (C). Ly30 contains cry1Aa, cry1Ac, cry1Ia, cry2Aa, and cry2Ab. G03 contains cry1Aa, cry1Ac, cry1Ca, and cry2Ab. HD-73 contains cry1Ac. 
to detect known cry sequences. However, it becomes less reliable than separate PCR (Lin et al., 2000). Another method is PCR-RFLP can identify known and unknown cry genes with only several pairs of primers. However, it becomes complicated, tedious, and time-consuming for analyzing multiple genes. It also ignores some variances in the conserved region (Yu et al., 1998). More importantly, PCR does not allow the rapid, parallel, and high throughput detection and identification of microbes. F. Song identified 14 known cry genotype with three universal primers and the corresponding enzymes, in the $3^{\text {rd }}$-level (Song et al., 2003); scholars from Israel obtained cry genes by PCR using five universal primers, and then identified 20 cry genotypes (Ben-Dov et al., 1997) by using specific primers. In this study, 45 known cry genotypes can be identified by probes. It fully reflects that the DNA microarray is an advantage.

The design and selection of probes are essential for the quality and application of a microarray. It is particularly important to use bioinformatic tools to explore the details of related genes in designing and optimizing probes.

The probes should be able to not only detect, but also correctly classify cry genes. There are currently 375 known cry sequences. The similarity among the $4^{\text {th }}$ level sequences is greater than $95 \%$. It is not possible to design an oligonucleotide probe that is able to correctly detect and type all cry genes at this level. As a result, we designed probes to distinguish sequences at the $1^{\text {st }}, 2^{\text {nd }}$, and $3^{\text {rd }}$ levels with a reasonable specificity level. At the $3^{\text {rd }}$ level, some sequences have a $75 \%$ similarity. It is difficult to design proper specificity probes Consequently, we relaxed the criteria, such as Tm, length, E value, and specificity score, and even designed two separate probes for some sequences (for example, $c r y l A b$ ). It is not possible to find one or two probes that could detect all cryl genes so we designed three probes which contain almost all the cryl genes (Liu et al., 2004).

In this study, the detection and typing of cry genes were based on TPPS. Any cry gene in the NCBI can hybridize with three corresponding probes. If a new cry gene exists in a strain, it will be unable to hybridize with all corresponding three-tier probes. Analysis of the hybridization profile can reveal the new cry gene. If a strain has more than one type of new cry genes (i. e. crylA $a$ and $\operatorname{cry} l A$ ), this method will be unable to reveal them (Jaroslaw et al., 2005).

Fluorescence labeling of genomic DNA is another key step of chip-based detection. It is not possible to design one or a few sets of primers for labeling all cry genes simultaneously by PCR amplification because there are a large number of diverse cry genes. Thus, conventional PCR-based chip detection is not applicable here.
Labeling of genomic DNA usually employs random primed nucleotide synthesis. This method can generate short fluorescent-labeled DNA. Due to its complexity, genomic DNA was first sheared with an ultrasonic processor (Vibra-Cell) before labeling. Therefore, it is not necessary to sonicate DNA prior to labeling. Since a large amount of genomic DNA is used for labeling, a high concentration of Klenow DNA polymerase should be used. If not, low efficiency of labeling results. In addition, the amount of random primer should be optimized so that the product is $1000 \mathrm{bp}$ or shorter. A large DNA fragment could cause the hybridization signal to decrease due to the spatial effect.

Since the random labeling method does not have a selective amplification step of target genes, the content of target genes is very low, leading to a low hybridization signal on the oligo chip. To counteract these drawbacks, it is necessary to use several dozen or even one hundred micrograms of genomic DNA to label them. In addition, the labeled target has to be concentrated and purified before hybridization. High PMT and power settings are necessary during array scanning. These operations lead to high background and increased difficulty level (Volokhov et al., 2002; Wang et al., 2003). Sometimes inconsistent results may be obtained using a chip to detect genes in the same strain. However, it may be reduced by a higher hybridization temperature. This inconsistency may be caused by random primed DNA labeling which requires multiple trials to determine the cry genes in $\mathrm{Bt}$.

Although sensitivity and consistency need to be improved, our study demonstrates that hierarchical oligonucleotide microarray is a high throughput assay capable of realistically reflecting all functional genes without PCR amplification of the target fragment (Wu et al., 2001; Zhou, 2003). Compared to the PCR method, the chip-based assay has more application prospects.

\section{CONCLUSIONS}

Our study demonstrates that hierarchical oligonucleotide microarray is a high throughput assay capable of realistically reflecting all functional genes without PCR amplification of the target fragment, although the sensitivity and consistency need to be improved.

\section{ACKNOWLEDGEMENTS}

This study was supported by 973 Project $\left(\mathrm{N}^{\circ}\right.$ 2009CB118902, 2007CB109203), and 863 Plan $\left(\mathrm{N}^{\circ}\right.$ 2006AA10A212), China. 


\section{RESUMEN}

Aplicación de microarreglo de oligonucleótidos en la detección y tipificación génica de genes cry en Bacillus thuringiensis. Se desarrolló un ensayo paralelo, rápido, de alto rendimiento, basado en microarreglo de oligonucleótidos para la detección y tipificación génica confiable de tres genes cry (cryl, cry 2 y cry 9 ) en Bacillus thuringiensis $(\mathrm{Bt})$. Después de la no reacción de cadena polimerasa (PCR), el ADN genómico de Bt amplificado se marcó con fluorescencia usando primer al azar. Las correspondientes sondas de oligonucleótido fueron diseñadas por los diferentes genes cry en $\mathrm{ADN}$ genómico de Bt que pueden ser hibridados después de análisis cluster y se imprimieron en portaobjetos de vidrio. Este microarreglo ha detectado e identificado sin ambigüedad los genes cry en 10 aislamientos y Bt de referencia. Nuestros datos demuestran que el microarreglo es simple y rápido para la detección y tipificación génica de genes. Este tipo de ensayo es además una herramienta potencialmente valiosa para identificación y caracterización de genes funcionales bacterianos en general.

Palabras clave: microarreglo de oligonucleótidos, genes cry, tipificación génica, marcación con primer al azar, bioinformática.

\section{LITERATURE CITED}

Ben-Dov, E., A. Zaritsky, E. Dahan, Z. Barak, R. Sinai, Manasherob, et al. 1997. Extended screening by PCR for seven cry-group genes from field-collected strains of Bacillus thuringiensis. Appl. Environ. Microbiol. 63:4883-4890.

Bodrossy, L., N. Stralis-Pavese, J.C. Murrell, S. Radajewski, A. Weilharter, and A. Sessitsch. 2003. Development and validation of a diagnostic microbial microarray for methanotrophs. Environ. Microbiol. 5:566-582.

Bourque, S.N., J.R. Valéro, J. Mercier. M.C. Lavoie, and R.C. Levesque. 1993. Multiplex polymerase chain reaction for detection and differentiation of the microbial insecticide Bacillus thuringiensis. Appl. Environ. Microbiol. 59:523-527.

Brown, P. 2000. Genomic DNA labeling protocol. Available at http://cmgm.stanford.edu/pbrown/ protocols/4_genomic.html (accessed October 2007).

Ceron, J., A. Ortiz, R. Quintero, L. Guereca, and A. Bravo. 1995. Specific PCR primers directed to identify cry $I$ and cryIII genes within a Bacillus thuringiensis Strain collection. Appl. Environ. Microbiol. 61:3826-3831.
Crickmore, N. 2003. Full list of delta-endotoxins. Available at http://www.lifesci.sussex.ac.uk/home/ Neil_Crickmore/Bt/toxins2.html (accessed October 2006).

Gabig, M., and G. Wegrzyn. 2001. An introduction to DNA chips: Principles, technology, applications and analysis. Acta Biochim. Pol. 48:615-622.

Hwang, T.S., J.K. Jeong, M. Park, H.S. Han, H.K. Choi, and T.S. Park. 2003. Detection and typing of HPV genotypes in various cervical lesions by HPV oligonucleotide microarray. Gynecol. Oncol. 90:5156.

Jaoua, S., N. Zouari, S. Tounsi, and R. Ellouz. 1996. Study of the $\delta$-endotoxins produced by three recently isolated strains of Bacillus thuringiensis. FEMS Microbiol. Lett. 145:349-354.

Jaroslaw, L., B. Alejandra, B. Roland, and M. Luke. 2005. Assessment of cryl Gene Contents of Bacillus thuringiensis Strains by Use of DNA Microarrays. Appl. Environ. Microbiol. 71:5391-5398.

Juárez-Perez, V.M., M.D. Ferrandis, and R. Frutos. 1997. PCR-Based approach for detection of novel Bacillus thuringiensis cryV genes. Appl. Environ. Microbiol. 63:2997-3002.

Lin, Y., Z.P. Huang, J.W. Chen, B.W. Huang, and X. Guan. 2000. Strategies and advances on PCR identification for insecticidal crystal protein genes of Bacillus thuringiensis. Chin. J. Agric. Biotechnol. 8:56-58 (in Chinese).

Liu, X.G., F. Song, S.Y. Wen, S.Q. Wang, D.F. Huang, and J. Zhang. 2004. Study of microarray detection method of cry genes from Bacillus thuringiensis. Sci. Agric. Sin. 37:987-992 (in Chinese).

Small, J., D.R. Call, F.J. Brockman, T.M. Straub, and D.P. Chandler. 2001. Direct detection of 16S rRNA in soil extracts by using oligonucleotide microarrays. Appl. Environ. Microbiol. 67:4708-4716.

Song, F., J. Zhang, A. Gu, Y. Wu, L. Han, K. He, et al. 2003. Identification of crylI-type genes from Bacillus thuringiensis strains and characterization of a novel cryll-type gene. Appl. Environ. Microbiol. 69:52075211.

Volokhov, D., A. Rasooly, K. Chumakov, and V. Chizhikov. 2002. Identification of Listeria species by microarray-based assay. J. Clin. Microbiol. 40:47204728.

Wang, D., H. Gao, R. Zhang, X. Ma, Y. Zhou, and J. Cheng. 2003. Single nucleotide polymorphism discrimination assisted by improved base stacking hybridization using oligonucleotide microarrays. Biotechniques 35:300-302, 304, 306. 
Wen, S.Y., H. Wang, O.J. Sun, and S.Q. Wang. 2003. Rapid detection of the known SNPs of CYP2C9 using oligonucleotide microarray. World J. Gastroenterol. 9:1342-1346.

Wu, L., D.K. Thompson, G. Li, R.A. Hurt, J.M. Tiedje, and J. Zhou. 2001. Development and evaluation of functional gene arrays for detection of selected genes in the environment. Appl. Environ. Microbiol. 67:5780-5790.

Yao, J., J. Zhang, F. Song, C. Li, X. Liu, and D. Huang. 2003. Cloning and expression of crylAc gene from a novel Bacillus thuringiensis Ly30 strain. Chin. J. Agric. Biotechnol. 11:516-519 (in Chinese).
Yu, J.X., Y. Pang, J.Y. Liu, Y.J. Zhang, and M.Q. Xu. 1998. Screening of novel crystal protein genes from soil-collected Bacillus thuringiensis by PCR-RFLP. p. 43. In $7^{\text {th }}$ International Colloquium on Invertebrate Pathology and Microbial Control and $4^{\text {th }}$ International Conference on Bacillus thuringiensis, Sapporo, Japan. August 23-28. Society for Invertebrate Pathology, Marceline, Missouri, USA.

Zhou, J.Z. 2003. Microarrays for bacterial detection and microbial community analysis. Curr. Opin. Microbiol. 6:288-294. 